\title{
Influence of fertilizers on the microflora of the soil and rhizophora of mustard
}

\author{
Bulyhin S. ${ }^{1}$, Krolevets $0 .{ }^{2}$, Kotsareva N. ${ }^{3}$, Kovalenko A. ${ }^{4}$ \\ ${ }^{1}$ National University of Life and Environmental Sciences of Ukraine \\ 15 Heroiv Oborony Str., Kyiv, 03041, Ukraine \\ ${ }^{2}$ Federal State Autonomous Educational Institution of Higher Education «Belgorod State University» \\ 85 Pobiedy Str., Bielhorod, 308501, Russia, ${ }^{3,}{ }^{4}$ Bielgorod State Agrarian University named after V. Ya. \\ Gorin \\ 1 Vavilova Str., Maiskyi village, Bielgorod district, Bielgorod oblast, 308503, Russia \\ e-mail: ${ }^{1}$ s.bulygin@ukr.net, ${ }^{2}$ krolevets@inbox.ru, ${ }^{3}$ knv1510@mail.ru, ${ }^{4}$ mycobacteria@rambler.ru \\ ORCID: ${ }^{30000-0002-2701-6331 ~}$
}

Goal. To determine the influence of fertilizers on the species composition of the microflora of the soil under mustard. Methods. The sowing of mustard seeds was carried out in a cardboard container with an area of 142 $\mathrm{cm} 2$, which was filled with typical chernozem. Monitoring of indicators of soil was carried out twice: before sowing (indigenous microflora), and at the end of vegetation of mustard. Analysis of microflora of typical chernozem was performed by growing colonies of soil microorganisms on solid nutrient media by the method of cultivation. Results. After the cultivation of mustard in the variant without fertilization, the number of colonies was reduced to 75 , in the variant with the native form of NPK - up to 88, in the variant with nanostructured forms of NPK - up to 79. They fixed a decrease in the number of bacteria colonies from 53 (dilution - $10-$ 4) to 12 (dilution - 10-6) on GRM medium in the test sample of the soil before planting. The cultivation of mustard without fertilizer resulted in a reduction of colonies of bacteria to $20 ; 7$; and 3 at dilution $10-4 ; 10-$ $5 ; 10-6$ accordingly. With fertilizers, the number of colonies after incubation was higher than without their use. The same trend was noted in the number of microorganisms. After incubation without fertilizer and nanostructured forms of NPK, the number of colonies of bacteria was decreased in 6 times at the dilution of $10-2$, and incubation without the native form of NPK - in 5.4 times. Conclusions. The positive influence of nanostructured forms of NPK on the microflora of the soil is determined. They promote the preservation of beneficial microorganisms that form biocenosis of microorganisms in the root and near-root zones of plants, suppress pathogenic microflora, increase soil fertility as compared to the native form of fertilizers.

Key words: nanostructured form of NPK, mycorrhiza, root surface, colonies of bacteria, number of microorganisms.

DOI: https://doi.org/10.31073/agrovisnyk202003-02

Soil is an important part of the biosphere and consists of two main components: mineral and organic. The main property of the soil is fertility, which depends on the vital activity of organisms. Only soil combines living and nonliving materials [1].

Soil is the main source of food, which provides $95-97 \%$ of food resources for the world's population. At the same time human activities become the dominant factor in soils destruction and a decrease their fertility [2].

The most detailed research of soils, plants and fertilizers interaction can be done in long-term stationary experiments with the systematic use of fertilizers. In such experiments exceptional conditions of standardization are created allowing better examine the effects of climate and agrometeorological conditions on crops, soils, and factors, which regulate soil fertility [3-6].

The quantitative and species (qualitative) composition of the soil microbiota varies depending on regional and climatic conditions, season, temperature, chemical composition and physical properties, humidity, environmental reaction $(\mathrm{pH})$ and its processing method. In sandy and stony soils, as well as in soils without vegetation there are fewer microorganisms than in arable and especially fertilized soils. The content of microorganisms in soil increases from north to south. Soil color and smell are exerted by certain types of actinomycetes and molds. Most soil microorganisms are able to develop at a neutral $\mathrm{pH}$, high relative humidity at temperatures from 25 to $45^{\circ} \mathrm{C}$ [7].

The largest number of microorganisms is contained in the upper layer $-5-15 \mathrm{~cm}$. There is a certain relationship between soil fertility and the content of microorganisms in it. Fertile soils are biologically active. Calculations have shown that each hectare of infertile soils contains 2.5-3.0 tons of microbial mass, and highly fertile ones have up to 16 tons.

Soil microorganisms are in a complex biocenosis, characterized by antagonistic and symbiotic relationships, both among themselves and with plants. The species composition of soil microbiota changes with the soil depth changes. Aerobic saprophytic organisms that can decompose complex organic compounds predominate in the upper layers, which contain many organic substances and have good aeration. Deepening into the soil the number of microorganisms decreases and at a depth of 4-5 m they are practically absent. There is not any air and the number of anaerobic bacteria increases [8]. Nitrogen-fixing and nitrifying bacteria 
function in the soil, ammonification bacteria that cause mineralization of plant remains, animal corpses, urea decomposition bacteria that macerate fiber, which cause various types of fermentation (lactic acid, butyric acid, acetic acid, etc.).

The permanent inhabitants of the soil include various putrefaction mainly spore-forming, aerobic bacteria (Bacillus mycoides, Bac. Subtilis, Bac. Mesentencus, etc.) and anaerobic bacteria (Cloctridium sporogenes, $\mathrm{Cl}$. Putrificum, Cl. Perfringens, Cl. Botulinum, Cl. Chauvoei etc.), as well as thermophilic bacteria, cocci and other forms. Among saprophytic cocci most common are micrococci (Micrococcus albus, Mic. Reseus, Mic. Flavus).

E. coli, pathogens of typhoid fever, salmonella, dysentery can enter the soil with feces, but there are no conditions in the soil for their reproduction and they gradually die off. The detection of E.coli and Proteus in significant quantities is an indicator of soil contamination with feces and indicates a sanitary-epidemiological dysfunction [9].

Pathogenic rods (the causative agent of anthrax, botulism, tetanus, gas gangrene) are able to persist in the soil for a long time. Bacillus anthracis spores have been stored over 15 years. Therefore, the soil plays a major role in the epidemiology of tetanus, gas gangrene, botulism. Soil plays a significant role in the spread of leptospirosis, brucellosis, foodborne infections, enterovirus infections. For pathogens of actinomycosis, deep mycoses and mycotoxicoses the soil is a natural ecosystem [10].

The purpose of the research is to identify the effect of fertilizers on the species composition of soil microbiota during the cultivation of mustard.

Materials and research methods. The research was conducted under the conditions of vegetative experience. Sowing of mustard seeds was carried out in cardboard containers of $142 \mathrm{~cm} 2$. The containers were filled with typical black soil. The soil mass in the tank is $443.8 \mathrm{~g}$. Experiment scheme: Without fertilizers - control. The native form of nitroammophoska ( $0.5 \mathrm{~g}$ per container). Nanostructured form of nitroammophoska (0.652 g capacity).

In each container 20 mustard seeds were sown. The sowing date is 4.10.18. Seeds were laid out on the surface and sprinkled with soil $1 \mathrm{~cm}$, which increased the mass of containers to $598 \mathrm{~g}$. The experiment was repeated three times.

After sowing one carried out watering. Artificial lighting for plants was used. Watering was carried out every 7 days with $200 \mathrm{ml}$ of water per container. The observation was carried out for 8 weeks (until 11/30/18). Soil indicators were monitored twice: before sowing (autochthonous microflora) and at the end of plant cultivation from the rhizosphere zone. Analysis of the microbiota of typical black soil was carried out by seeding soil diluted in solid nutrient media [11 - 13].

Solid nutritional media were prepared for sowing: Levin media (for bacteria of the E.coli group), timing (for analysis of total bacterial contamination), Czapek's media (for fungi activity). The GRM medium is intended for the cultivation and counting of the total number of bacteria and the quantitative determination of microbial contamination.

The number of microorganisms was taken into account in the soil before the sowing of mustard and in the rhizospheric soil horizon after growing the plants.

Results. After taking into account the number of soil microorganisms, grown colonies and individual microorganisms were analyzed according to morphological characteristics determined genus. The following microorganisms were found in the groupings:

Pink round colonies with a wavy edge have been formed on Levin's medium. According to microscopy it is a long, movable, gram-positive, aerobic, spore-forming rod bacterium (Pic. 1), which allows us to determine the bacterium as bacteria of Bacillus genus.
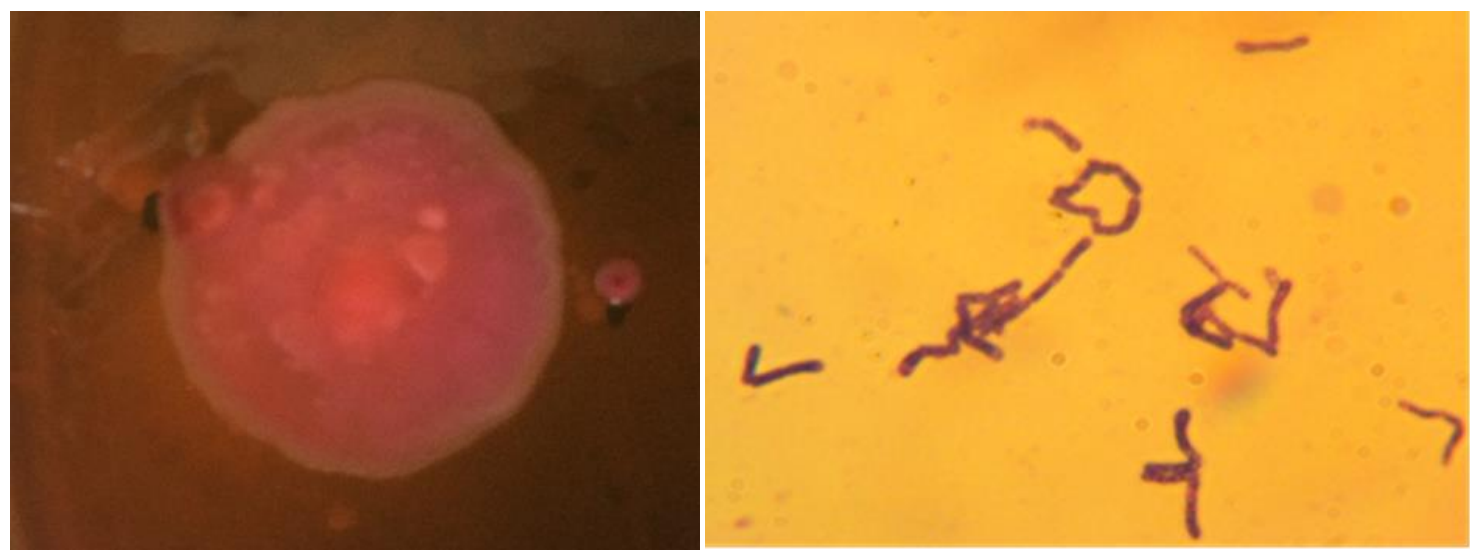

Pic. 1. Bacteria colony of genus Bacillus in Levin's medium. Fixed micropreparation from the colony. Zoom x1000 with immersion

Rounded colonies with a purple center are also found on Levin's medium (Pic. 2). The bacteria rod is aerobic, gram-negative, non-pore, movable, short. This allows us to reckon the bacteria in genus Pseudomonas. 

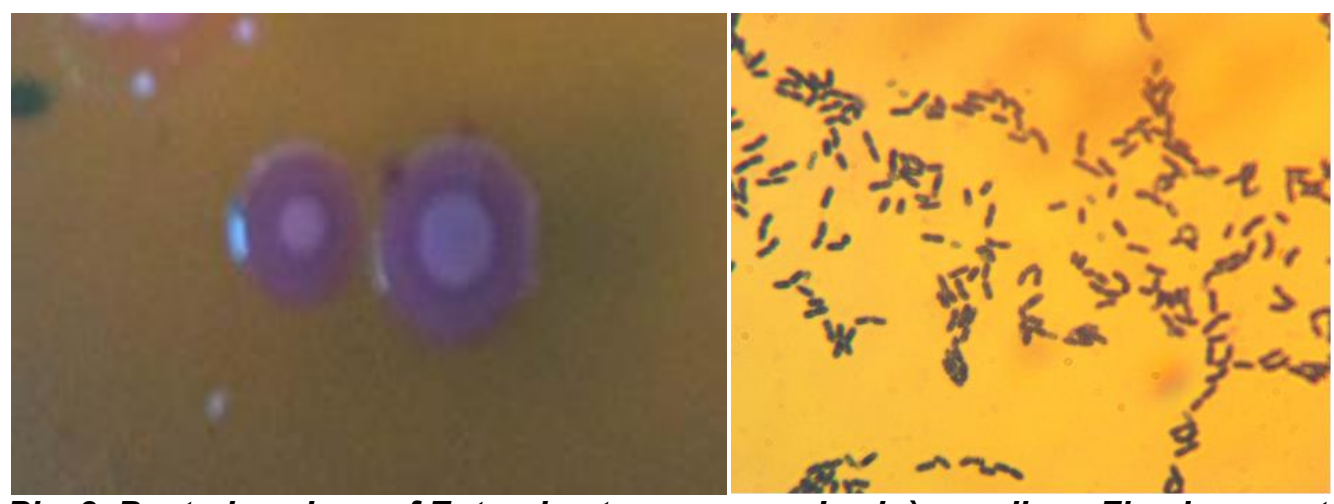

Pic. 2. Bacteria colony of Enterobacter genus on Levin's medium. Fixed gram-stained micropreparation colony Pseudomonas. Zoom x1000 with immersion
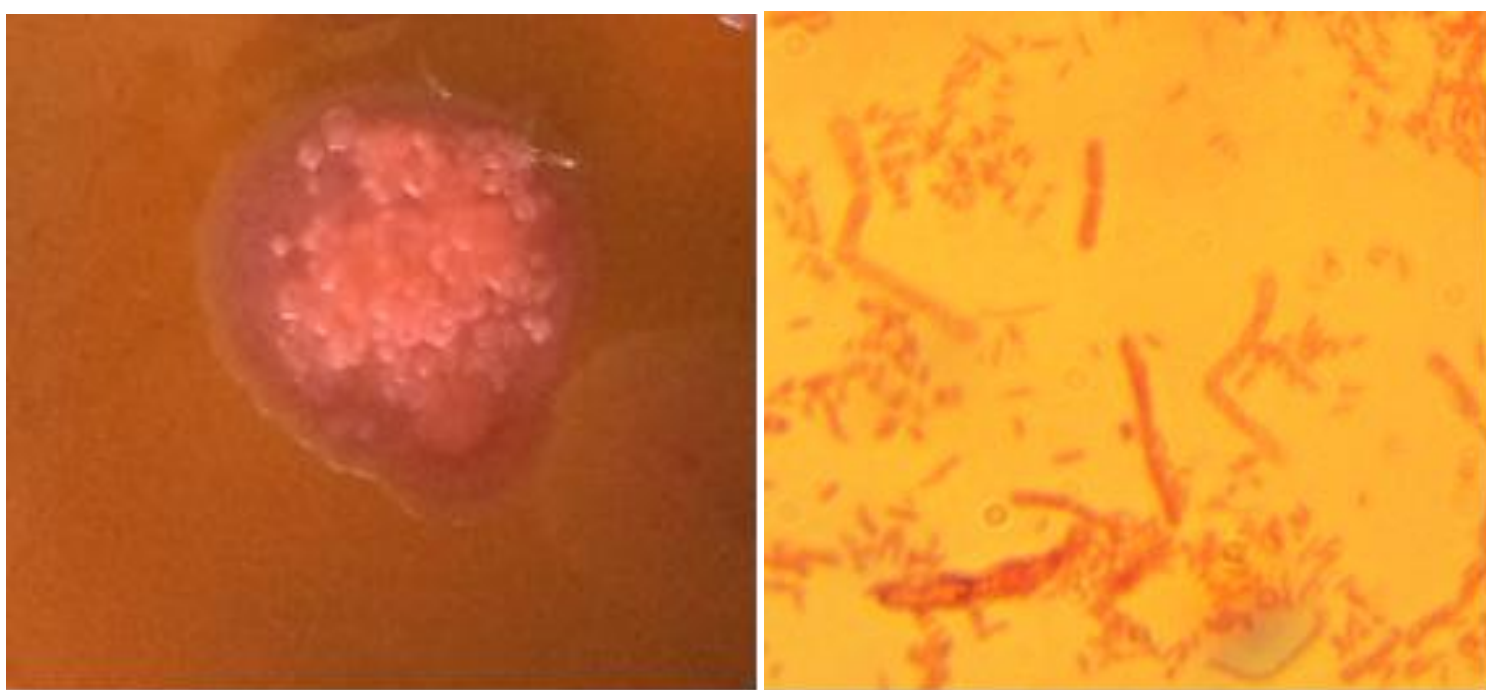

Pic. 3. Bacteria colony of genus Enterobacter on Levin's medium. Fixed gram-stained micropreparation. Zoom x1000 with immersion

Census for the number of microorganisms on Levin's medium in the soil before mustard sowing indicates their development at the level of 276 thousand CFU/g (Table 1). After the mustard cultivation in the variant without fertilizing the number of microorganisms decreased to 75 thousand CFU/g, with the introduction of the native form of nitroammophoska - up to 88 thousand and with nanostructured form of nitroammophoska - up to $79 \mathrm{CFU} / \mathrm{g}$ of rhizospheric soil. Thus, growing mustard without fertilizers and with fertilizers decreased the number of colonies and microorganisms by 3.6 times (dilution 10-2).

1. The effect of fertilizers on the microbiological parameters of the soil and mustard root surface on Levin's medium

\begin{tabular}{|c|c|}
\hline Experiment variants & Number of bacteria, thousand CFU/g of soil \\
\hline Soil before sowing of mustard & $900,0 \pm 87,2$ \\
\hline \multicolumn{2}{|c|}{ Rhizospheric soil (after mustard growing ) } \\
\hline Without fertilizers & $100,0 \pm 11,3$ \\
\hline Native form of nitroammophoska & $200,0 \pm 19,8$ \\
\hline Nanostructured form of nitroammophoska & $100,0 \pm 16,8$ \\
\hline
\end{tabular}

On the GRM medium was formed a large connected colony of white-colored bacteria, dull, limited wrinkled. Microscopy has determined short bacteria rod with a rounded end. The bacterium is gram-negative, sporeforming, aerobic, motionless, forms chains (Pic. 4), which allows preliminary identify it as Bacillus subtilis.

On the GRM medium under aerobic cultivation was formed rootlike, similar to fungus mycelium, gray-white color colony of bacteria Bacillus mycoides. The bacteria rod is gram-positive, spore-forming, and motionless. 


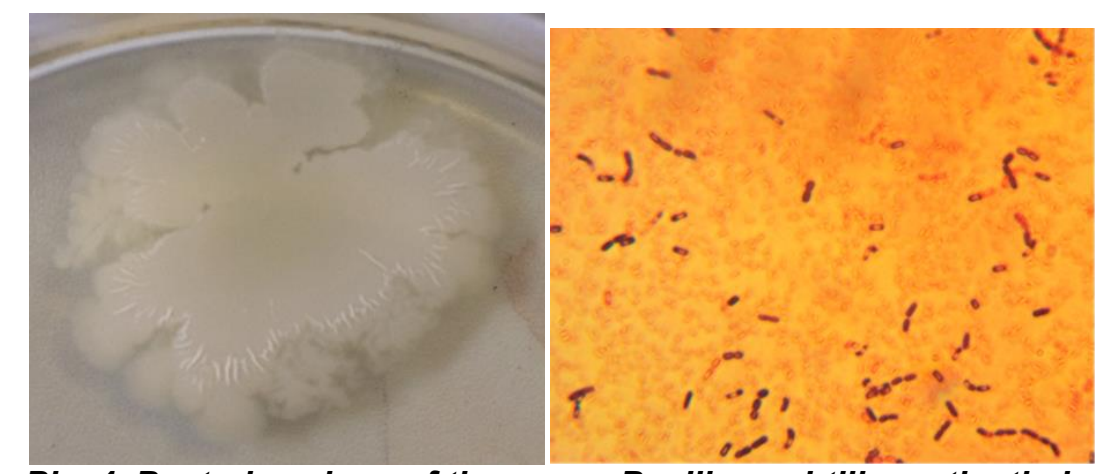

Pic. 4. Bacteria colony of the genus Bacillus subtilis on the timing medium. Fixed micropreparation gram-stained colony. Zoom x1000 with immersion

On the GRM mediumin the soil before mustarde sowing it was found the number of bacteria at the level of 530 thousand CFU/g (Table 2). Mustard cultivation without fertilizers leadded to decreasing to 200 thousand $\mathrm{CFU} / \mathrm{g}$ of rhizospheric soil. With the introduction of fertilizers the development of microorganisms was better.

\begin{tabular}{|c|c|}
\hline Experiment variants & Number of bacteria, thousand CFU/g of soil \\
\hline Soil before sowing of mustard & $900.0 \pm 43.7$ \\
\hline \multicolumn{2}{|c|}{ Rhizospheric soil (after mustard growing ) } \\
\hline Without fertilizers & $100.0 \pm 11.4$ \\
\hline Native form of nitroammophoska & $200.0 \pm 18.7$ \\
\hline Nanostructured form of nitroammophoska & $100.0 \pm 9.3$ \\
\hline
\end{tabular}

On the Czapek's media the development of micromycetes was found. Before mustard sowing one calculated 58 thousand CFU/g of fungi in the soil (Table 3). After mustard growing without fertilizing and with the use of nanostructured forms of nitroammophoska the number of micromycetes has decreased by 6 and 5.4 times, respectively.

\section{Effect of fertilizers on the microbiological parameters of the soil and mustard root surface on} Czapek's media

\begin{tabular}{|c|c|}
\hline Experiment variants & Number of bacteria, thousand CFU/g of soil \\
\hline Soil before sowing of mustard & $900.0 \pm 87.3$ \\
\hline \multicolumn{2}{|c|}{ Rhizospheric soil (after mustard growing ) } \\
\hline Without fertilizers & $100.0 \pm 9.4$ \\
\hline Native form of nitroammophoska & $200.0 \pm 19.8$ \\
\hline Nanostructured form of nitroammophoska & $100.0 \pm 9.2$ \\
\hline
\end{tabular}

\section{Conclusions}

Thus, a positive effect on the soil microbiota of introducing nanostructured forms of nitroammophoska has been established allows us to preserve beneficial microorganisms, which contribute to the formation of the microorganisms microcenosis in rhizosphere and root zones of plants; suppression of pathogenic microflora, increasing soil fertility compared with the native form of fertilizers.

But it is in another point - the identification of individual colonies of the azotobacter or Bacillus subtilis does not yet indicate beneficial microorganisms preservation. One should conduct additional researches is this case.

\section{References}

1. Dobrovolskiy, G. V., Kust, G. S., \& Chernov, I. Yu. (2012). Pochvy v biosfere i zhizni cheloveka [Soils in the biosphere and human life]. Moscow: FGBOU VPO MGUL. [In Russian].

2. Bazdyrev, G. I., Loshakov, V. G., \& Puponin, A. I. (2004). Zemledelie [Agriculture]. Moscow: Kolos. [In Russian].

3. Patyka, V. P., \& Symochko, L. lu. (2016). Mikrobiolohichnyi monitorynh gruntu pryrodnykh ta transformovanykh ekosystem Zakarpattia Ukrainy [Microbiological soil monitoring of natural and transformed ecosystems of Transcarpathia Ukraine]. Microbiological journal, 75(2), 21-31. [In Ukrainian].

4. Gadzalo, Ya. M., Patyka, N. V., \& Zaryshnyak, A. S. (2015). Agrobyologia rizosfery rasteniy [Agrobiology of the rhizosphere of plants]. Kiev: Agrarian Science. [In Russian]. 
5. Volkohon, V. V., Pyrih, O. V., \& Brytan, T. lu. (2018). Spriamovanist gruntovo-mikrobiolohichnykh protsesiv za vplyvu orhanichnykh i mineralnykh dobryv [Orientation of soil-microbiological processes under the influence of organic and mineral fertilizers]. Bulletin of Agricultural Science, 6, 5-11. doi: 10.31073/agrovisnyk201806-01. [In Ukrainian].

6. Volkohon, V. V. (2018). Silskohospodarska mikrobiolohiia v Ukraini: zdobutky, problemy, perspektyvy [Agricultural microbiology in Ukraine: achievements, problems, prospects]. Bulletin of Agricultural Science, 11, 20-27. doi: 10.31073/agrovisnyk 201811-03. [In Ukrainian].

7. Nikitin, D. I. (1979). Pochvennaya mikrobiologiya [Soil microbiology]. Moscow: Kolos. $4^{\text {th }}$ ed. [In Russian].

8. Kauricheva, I. S. (1989). Pochvovedenie [Soil science]. Moscow: Agropromizdat. $4^{\text {th }}$ ed. [In Russian].

9. Netrusov, A. I. (2004). Ekologiya mikroorganizmov: ucheb. [Ecology of microorganisms: textbook]. Moscow: Academy. [In Russian].

10. Asonov, N. R. (1988). Praktikum po mikrobiologii [Microbiology Workshop]. Moscow: Agropromizdat. [In Russian].

11. Volkohon, V. V., Berdnikov, O. M., Tokmakova, L. M., \& Larchenko, I. V. (2017). Rozvytok mikroorhanizmiv u ryzosferi roslyn vivsa holozernoho ta vrozhainist kultury za dii dobryv i biopreparatu mikrohuminu [The development of microorganisms in the rhizosphere of oat-holoseric plants and crop yields due to the action of fertilizers and microhuman biopreparation]. Bulletin of Agricultural Science, 2, 5-10. [In Ukrainian].

12. Bulyhin, S. Yu., \& Tonkha, O. L. (2018). Biological evaluation of the rationality of soil usage in agriculture. Agricultural Science and Practice, 5(1), 23-29. doi: 10.15407/agrisp5.01.023.

13. Volkohon, V. V., Pyrig, O. V., Volkohon, K. I., \& Dimova, S. B. (2019). Methodological aspects of determining the trend of organic matter mineralization synthesis processes in croplands. Agricultural Science and Practice, 6(1), 3-9. doi: 10.15407/ agrisp6.01.003. 